Journalof BANKING \&

FINANCE

\title{
Investment opportunities and market reaction to capital expenditure decisions
}

\author{
Kee H. Chung ${ }^{\mathrm{a}, *}$, Peter Wright ${ }^{\mathrm{a}}$, Charlie Charoenwong ${ }^{\mathrm{b}}$ \\ a The Fogelman College of Business and Economics, The University of Memphis, Memphis, TN \\ 38152, USA \\ ${ }^{\mathrm{b}}$ Department of Banking and Finance, Faculty of Commerce and Accountancy, Chulalongkorn \\ University, Phayathai Road, Bangkok 10330, Thailand
}

Received 2 February 1995; accepted 15 May 1997

\begin{abstract}
In this study, we argue that share price reaction to a firm's capital expenditure decisions depends critically on the market's assessment of the quality of its investment opportunities. We postulate that announcements of increases (decreases) in capital expenditures positively (negatively) affect the stock prices of firms with valuable investment opportunities. Contrarily, we predict that announcements of increases (decreases) in capital spending negatively (positively) affect the share prices of firms without such opportunities. Our empirical results are generally consistent with these predictions. Overall, empirical evidence supports our conjecture that it is the quality of the firm's investment opportunities rather than its industry affiliation which determines the share price reaction to its capital expenditure decisions. (c) 1998 Elsevier Science B.V. All rights reserved.
\end{abstract}

\section{JEL classification: G14}

Keywords: Investment opportunities; Tobin's q; Event study; Capital expenditure

\footnotetext{
*Corresponding author. Tel.: +1 901678 4642; fax: +1 901678 2685; e-mail: keechung@fogelman.memphis.edu.
} 


\section{Introduction}

Corporate managers are regularly faced with three major policy decisions capital expenditure decisions, dividend (payout) decisions, and financing decisions. Recently, a number of studies have rigorously examined the impact of announcements of corporate financing and dividend decisions on the market value of firms (see, for example, Masulis, 1980, 1983; Eades et al., 1985; Kalay and Lowenstein, 1985; Ofer and Siegel, 1987; Barclay and Litzenberger, 1988; Lang and Litzenberger, 1989; Loderer and Mauer, 1992; Denis, 1994; Jung et al., 1996). However, empirical evidence on the valuation effects of announcements of corporate capital expenditure decisions is relatively sparse. In this study, we provide additional evidence on the impact of capital expenditure decisions on share prices.

McConnell and Muscarella (1985) examine the market reaction to capital expenditure decisions by industrial and public utility firms. They find that announcements of increases (decreases) in capital expenditures lead to significant positive (negative) stock returns for industrial firms. For public utility firms, however, they find that announcements of capital expenditure decisions do not have any material effect on stock returns. Chan et al. (1990) examine the market response to announcements of $R \& D$ spending by firms in both highand low-technology industries. They find that those firms in high-technology industries which announce increases in $\mathrm{R} \& \mathrm{D}$ spending, on average, experience positive abnormal returns, but those in low-technology industries experience negative returns. Chan et al. (1994) find that the stock market reacts positively to business relocation decisions that are motivated by business expansion or cost savings, but negatively to decisions that are motivated by capacity reduction or facilities consolidation.

Although previous studies make important contributions to furthering our understanding of the valuation effects of corporate investment decisions, they do not fully explain why resource allocation decisions of some companies are favorably received by the market, whereas similar decisions of other companies are negatively received by the market. While previous studies suggest that the market tends to react more favorably to the capital spending decisions of high-technology or industrial firms, their categorization of firms is ad hoc at best and lacks sound economic reasoning.

In this study, we argue that share price reaction to a firm's capital expenditure decisions depends critically on the market's assessment about the quality of the firm's investment opportunities. We postulate that announcements of increases (decreases) in capital spending will positively (negatively) affect the share prices of firms with valuable investment opportunities. For firms without such opportunities, however, we predict that announcements of increases (decreases) in capital spending negatively (positively) influence share prices. Although firms in high-technology industries may, on average, have better 
investment opportunities than firms in low-technology industries, it is quite possible that poorly managed firms in high-technology industries would have lower growth potential than well-managed firms in low-technology industries. The basic premise of our study is that it is a firm's growth prospects rather than its industry affiliation which determine the market's reaction to capital expenditure decisions. ${ }^{1}$

We use Tobin's $q$ ratio as an instrumental variable to classify our sample of firms into those with valuable investment opportunities and those without such opportunities. We find evidence that is generally consistent with our conjectures. We find that announcements of increases in capital spending result in positive share price changes among firms with Tobin's $q$ ratios of greater than unity. We also find that the market reacts favorably to the announcements of reduced capital expenditures when those announcements are made by low- $q$ companies. Empirical results also show that announcements of increases in capital expenditures made by low- $q$ companies in high-technology industries exert a negative impact on share price. Similarly, the market reacts negatively to announcements of decreases in capital spending made by high- $q$ companies in low-technology industries. These results are consistent with our conjecture that the firm's growth prospects rather than its industry affiliation determine the market's reaction to capital expenditure decisions.

The paper is organized as follows. In Section 2, we present our hypotheses. Sample selection procedure and descriptive statistics are detailed in Section 3. In Section 4, we discuss the methodology and present the empirical results. The paper ends with a brief summary.

\section{Tobin's $q$ and the market reaction to capital expenditure decisions}

Lately numerous studies utilize Tobin's $q$ as an empirical proxy for a firm's investment opportunity set. Lang et al. (1989) employ Tobin's $q$ ratio as an empirical proxy for the quality of a firm's current and anticipated projects. They find that takeovers of poorly managed targets (i.e. firms with $q$ ratio of less than unity) by well-managed bidders (i.e. firms with $q$ ratio of greater than unity) have higher bidder, target, and total gains. In a similar vein, Lang et al. (1991) use Tobin's $q$ to distinguish firms which have valuable investment opportunities from those which do not, and find evidence that bidder returns are negatively related to cash flows for low- $q$ bidders but not for high- $q$ bidders. In addition, Lang and Litzenberger (1989) Pilotte (1992), Denis (1994)

\footnotetext{
${ }^{1}$ It is important to note that firms' growth potential is determined not only by their industry characteristics (e.g. entry barrier or monopoly power) but also by many other firm-specific factors, such as managerial competence and locational advantages.
} 
and Jung et al. (1996) use Tobin's $q$ ratio as an empirical proxy for the firm's investment opportunities.

Following these studies, we view firms with $q$ 's in excess of unity as those with valuable investment opportunities. Since these firms are expected to have positive net present value projects, announcements by such firms of increases in capital expenditures are expected to be favorably received by the market. On the other hand, announcements of capital expenditure reduction by such firms may be viewed as non-value maximizing decisions by the market. These considerations lead to our first hypothesis:

Hypothesis 1. For firms with Tobin's $q$ ratios of greater than unity, announcements of increases (decreases) in capital expenditures have a positive (negative) effect on share price.

Conversely, firms with $q$ 's of less than unity may lack valuable investment opportunities. Because these firms' future projects are not expected to be lucrative, announcements of capital expenditure increases by such firms may be unfavorably viewed by the market. Indeed, investors may prefer that these firms reduce capital expenditures. These considerations lead to our next proposition:

Hypothesis 2. For firms with Tobin's $q$ ratios of less than unity, announcements of increases (decreases) in capital expenditures have a negative (positive) effect on share price.

In the following sections, we employ both the standard event-study methodology and regression analysis to empirically test these hypotheses.

\section{Sample selection procedure and data description}

Data on capital expenditure announcements are collected from Nexis/Lexis services over the 15 year period 1981-1995. For each capital expenditure decision, an announcement date is identified as the earlier of the date the capital spending decision is announced in the Wall Street Journal or the date the announcement first appears in other major newspapers/newswires covered by Nexis/Lexis services. The search is conducted using key words such as "capital expenditures", "capital outlays", "capital spending", "long term expenditures," and "planned expenditures". These key words initially identify 425 capital expenditure announcements. However, only the announcements meeting the following criteria are maintained in the sample:

1. Announcements must be directly pertinent to capital spending decisions. We include in the sample only the announcements of changes (at either 
corporate or divisional level) in capital expenditures. ${ }^{2}$ Thus, announcements of corporate acquisitions, tender offers, or short-term strategic alliances are all excluded from the sample.

2. Announcements must contain definite plans rather than conjectures about the future. Moreover, announcements must include information about the approximate size and the general use of the funds.

3. Announcements must be made in isolation of other announcements (i.e. announcements on sales, earnings, dividend, equity or debt offerings, or top management changes) which occur within three days on either side of the announcements. This procedure minimizes the effect of extraneous information on stock prices.

4. Announcements must be made by companies whose complete daily return data during the study period are available from the NYSE/AMEX or NASDAQ files on the Center for Research in Security Prices (CRSP) tape.

These restrictions eliminate 67 announcements from the initial sample. In addition, 50 announcements are made by companies that are not included in the Compustat files. Hence our final dataset comprises 308 capital expenditure announcements.

We calculate Tobin's $q$ ratio for each company using the method in Lindenberg and Ross (1981). Tobin's $q$ is measured as of the year ending just prior to the capital expenditure announcement. Using data in the Compustat industrial files, GNP deflator, and bond yields, we first calculate the market value of firms and the replacement cost of assets (see Appendix A for a detailed explanation of the procedure). Tobin's $q$ is then obtained by dividing the market value by the replacement cost.

Table 1 presents the frequency of capital expenditure announcements made by the group of high- $q$ companies (i.e. $q \geqslant 1$ ) and by the group of low- $q$ companies (i.e. $q<1$ ) during each year of the study period. For the entire study period, our sample of high- $q$ companies made 73 announcements of capital expenditure increases and 33 announcements of capital expenditure decreases. For low- $q$ companies, there were 131 announcements of capital expenditure increases and 71 announcements of capital expenditure decreases. Hence our data show that announcements of "increases" in capital expenditures are more

\footnotetext{
${ }^{2}$ For companies with many divisions or subsidiaries, it is possible that the $q$ ratio of a division of the firm would be different from the firm's overall $q$ ratio, which is the average of divisional $q$ ratios. A meaningful analysis of stock market reactions to divisional capital expenditure announcements would require information on divisional $q$ ratios. Because we use Tobin's $q$ ratio of the firm for the purpose of classifying it into high- or low- $q$ group, rather than the divisional $q$ ratio, our results are subject to measurement error associated with $q$ ratio. To assess the sensitivity of our results to the measurement error, we also perform empirical analyses after all divisional capital spending announcements are dropped from the sample. The results, however, are qualitatively similar to those presented subsequently. Hence, for brevity, we report the results based on the whole sample.
} 
Table 1

Frequency distribution of capital expenditure announcements during the time period 1981-1995

\begin{tabular}{|c|c|c|c|c|c|c|}
\hline \multirow[t]{2}{*}{ Year } & \multicolumn{2}{|c|}{ Whole sample } & \multicolumn{2}{|c|}{ High- $q$ firms ${ }^{\text {a,b }}$} & \multicolumn{2}{|c|}{ Low- $q$ firms ${ }^{c}$} \\
\hline & Increase & Decrease & Increase & Decrease & Increase & Decrease \\
\hline 1981 & 26 & 2 & 10 & 0 & 16 & 2 \\
\hline 1982 & 16 & 20 & 7 & 8 & 9 & 12 \\
\hline 1983 & 8 & 3 & 4 & 1 & 4 & 2 \\
\hline 1984 & 6 & 0 & 1 & 0 & 5 & 0 \\
\hline 1985 & 12 & 10 & 4 & 3 & 8 & 7 \\
\hline 1986 & 10 & 16 & 4 & 2 & 6 & 14 \\
\hline 1987 & 15 & 4 & 6 & 2 & 9 & 2 \\
\hline 1988 & 12 & 1 & 5 & 1 & 7 & 0 \\
\hline 1989 & 10 & 4 & 5 & 2 & 5 & 2 \\
\hline 1990 & 20 & 5 & 8 & 0 & 12 & 5 \\
\hline 1991 & 18 & 14 & 8 & 3 & 10 & 11 \\
\hline 1992 & 18 & 15 & 4 & 9 & 14 & 6 \\
\hline 1993 & 11 & 3 & 2 & 0 & 9 & 3 \\
\hline 1994 & 12 & 5 & 3 & 1 & 9 & 4 \\
\hline 1995 & 10 & 2 & 2 & 1 & 8 & 1 \\
\hline Total & 204 & 104 & 73 & 33 & 131 & 71 \\
\hline
\end{tabular}

a Tobin's $q$ is calculated using the Lindenberg and Ross (1981) procedure.

b Firms with $q$ ratios of greater than unity.

c Firms with $q$ ratios of less than unity.

common among both group of companies. Our data also indicate that high- $q$ companies make fewer announcements of their capital spending decisions than do low- $q$ companies. ${ }^{3}$ This is perhaps because capital spending decisions of high- $q$ firms usually have significant strategic value, and therefore they may not publicize their decisions to the extent possible. ${ }^{4}$ If indeed high- $q$ firms tend to announce only those capital spending decisions that would have minor ramification for their competitive advantage, while concealing their investments with significant strategic value, our study will be subject to a sample selection bias. The bias will, however, work against the predicted stock price changes stipulated in our Hypotheses 1 and 2.

Table 2 presents the size of capital expenditure changes as measured by the percentage change from the previous year. Panel A presents the summary statistics for high- $q$ firms and panel B for low- $q$ firms. In each panel, the mean, median, minimum, maximum, and select percentile values of capital expenditure changes (in percent) are reported for the group of high-technology as well as for the group of low-technology firms. For our sample of high- $q$ firms, the

\footnotetext{
${ }^{3}$ An implicit presumption required for this observation is that the number of high- $q$ companies is approximately equal to the number of low- $q$ companies in the population.

${ }^{4}$ For low- $q$ companies, however, such a tendency would be less prominent because of the very nature of their investment opportunity set.
} 
Table 2

Descriptive statistics on capital expenditure changes

\begin{tabular}{|c|c|c|c|c|c|c|}
\hline & \multicolumn{2}{|c|}{ Whole sample } & \multicolumn{2}{|c|}{$\begin{array}{l}\text { High-technology } \\
\text { firms }^{\text {a }}\end{array}$} & \multicolumn{2}{|c|}{$\begin{array}{l}\text { Low-technology } \\
\text { firms }\end{array}$} \\
\hline & Increase $^{b}$ & Decrease & Increase & Decrease & Increase & Decrease \\
\hline \multicolumn{7}{|c|}{ Panel A: High-q firms ${ }^{\mathrm{c}, \mathrm{d}}$} \\
\hline Average & 28.81 & -26.00 & 24.21 & -19.73 & 32.82 & -31.22 \\
\hline Median & 25.00 & -25.00 & 20.00 & -16.00 & 29.00 & -28.50 \\
\hline Minimum & 2.00 & -70.00 & 3.00 & -50.00 & 2.00 & -70.00 \\
\hline 1st percentile & 2.00 & -70.00 & 3.00 & -50.00 & 2.00 & -70.00 \\
\hline 5th percentile & 5.00 & -58.00 & 5.00 & -50.00 & 3.00 & -70.00 \\
\hline 95 th percentile & 77.00 & -4.00 & 69.00 & -4.00 & 80.00 & -1.00 \\
\hline 99th percentile & 100.00 & -1.00 & 79.00 & -4.00 & 100.00 & -1.00 \\
\hline Maximum & 100.00 & -1.00 & 79.00 & -4.00 & 100.00 & -1.00 \\
\hline Sample size & 73 & 33 & 34 & 15 & 39 & 18 \\
\hline \multicolumn{7}{|c|}{ Panel B: Low-q firms } \\
\hline Average & 36.66 & -34.77 & 30.64 & -25.81 & 38.94 & -38.54 \\
\hline Median & 20.00 & -26.00 & 19.50 & -29.00 & 25.50 & -25.50 \\
\hline Minimum & 2.00 & -500.00 & 2.00 & -50.00 & 2.00 & -500.00 \\
\hline 1st percentile & 2.00 & -500.00 & 2.00 & -50.00 & 2.00 & -500.00 \\
\hline 5 th percentile & 5.00 & -65.00 & 5.00 & -48.00 & 5.00 & -90.00 \\
\hline 95 th percentile & 80.00 & -5.00 & 125.00 & -5.00 & 80.00 & -5.00 \\
\hline 99th percentile & 174.00 & -3.00 & 174.00 & -4.00 & 900.00 & -3.00 \\
\hline Maximum & 900.00 & -3.00 & 174.00 & -4.00 & 900.00 & -3.00 \\
\hline Sample size & 131 & 71 & 36 & 21 & 95 & 50 \\
\hline
\end{tabular}

a Sample firms are classified into high- or low-technology firms according to the classification scheme in Business Week's Annual R\&D Scoreboard.

$\mathrm{b}$ The change in capital expenditure is measured in terms of the percentage change from the previous year's figure.

c Tobin's $q$ is calculated using the Lindenberg and Ross (1981) procedure.

${ }^{\mathrm{d}}$ High- (low-) $q$ firms are defined as those firms with $q$ ratios of greater (less) than unity.

mean value of increases in capital budget is $28.81 \%$, while the mean value of decreases in capital budget is $-26 \%$. For low- $q$ firms, the corresponding figures are $36.66 \%$ and $-34.77 \%$, respectively. Overall, these results indicate that our sample of firms made significant year-to-year changes in their capital budget. The results also suggest that low- $q$ companies tend to make larger year-to-year capital spending changes than high- $q$ companies.

\section{Methodology and findings}

\subsection{Measuring abnormal returns}

We use the standard event study methodology to measure abnormal stock price movements around capital expenditure announcements. The estimation 
period is from -150 to -31 days prior to announcement. The event period is defined as 30 days before through 10 days after announcement. Daily stock return data during the study period ( -150 days before through 10 days after announcement) are obtained from the CRSP files. Let $R_{i t}$ designate the stock return of firm $i$ on day $t$. Then the abnormal return of firm $i\left(\mathrm{AR}_{i t}\right)$ during the event period is measured using the following formula:

$$
\mathrm{AR}_{i t}=R_{i t}-\left(\hat{\alpha}_{i}+\hat{\beta}_{i} R_{\mathrm{m} t}\right),
$$

where $R_{\mathrm{m} t}$ is the CRSP value-weighted market return on day $t$, and $\hat{\alpha}_{i}$ and $\hat{\beta}_{i}$ are Scholes-Williams estimates of market model parameters during the estimation period. 5

Next, the standardized abnormal return of firm $i$ on day $t\left(\mathrm{SR}_{i t}\right)$ during the event period is calculated using the following formula:

$$
\mathrm{SR}_{i t}=\frac{\mathrm{AR}_{i t}}{\hat{\sigma}_{i t}}
$$

where

$$
\hat{\sigma}_{i t}=\hat{\sigma}_{i}\left(1+\frac{1}{120}+\frac{\left(R_{\mathrm{m} t}-\bar{R}_{\mathrm{m}}\right)^{2}}{\sum_{\tau=-150}^{-31}\left(R_{\mathrm{m} \tau}-\bar{R}_{\mathrm{m}}\right)^{2}}\right)^{1 / 2} .
$$

In Eq. (3), $R_{\mathrm{m}}$ is the average market return during the estimation period and $\hat{\sigma}_{i}$ is the standard deviation of firm $i$ 's market model residuals. ${ }^{6}$

The average standardized abnormal return on day $t\left(\mathrm{SAR}_{t}\right)$ is then obtained by averaging the standardized abnormal return over all $i$, i.e. $\mathrm{SAR}_{t}=\sum_{i} \mathrm{SR}_{i t} l$ $N$, where $N$ is the number of announcements. The cumulative standardized abnormal return $\left(\mathrm{CSAR}_{\tau}\right)$ is measured by the intertemporal summation of the average standardized abnormal returns over a given period, i.e., $\mathrm{CSAR}_{\tau}=\sum_{\tau} \mathrm{SAR}_{t} /(\tau-v+1)^{1 / 2}$, where $\sum_{\tau}$ denotes the summation over $t=v$ through $\tau, v$ and $\tau$ are the beginning and ending day of each CSAR calculation respectively.

We then use the following statistics to test whether $\mathrm{SAR}_{t}$ differs from zero

$$
Z_{t}=\operatorname{SAR}_{t} \sqrt{N}
$$

\footnotetext{
${ }^{5}$ Scholes-Williams estimates of market model parameters are calculated using the formulae:

$\hat{\alpha}_{i}=\frac{1}{120} \sum_{t=-150}^{-31}\left(R_{i t}-\hat{\beta}_{i} R_{\mathrm{m} t}\right) ; \quad \hat{\beta}_{i}=\frac{\beta_{i}^{-}+\beta_{i}^{0}+\beta_{i}^{+}}{1+2 \rho_{\mathrm{m}}}$.

Here, $\beta_{i}^{-}, \beta_{i}^{0}$, and $\beta_{i}^{+}$are, respectively, the values of $\operatorname{Cov}\left(R_{i t}, R_{\mathrm{m} t-1}\right) / \sigma\left(R_{\mathrm{m} t}\right) \sigma\left(R_{\mathrm{m} t-1}\right), \operatorname{Cov}\left(R_{i t}, R_{\mathrm{m} t}\right) /$ $\sigma\left(R_{\mathrm{m} t}\right) \sigma\left(R_{\mathrm{m} t}\right)$, and $\operatorname{Cov}\left(R_{i t}, R_{\mathrm{m} t+1}\right) / \sigma\left(R_{\mathrm{m} t}\right) \sigma\left(R_{\mathrm{m} t+1}\right)$ during the estimation period $t=-150$ to $-31 . \rho_{\mathrm{m}}$ is the first-order autocorrelation coefficient of the value-weighted market return during the estimation period (see Scholes and Williams, 1977, p. 317).

${ }^{6}$ See Warner et al. (1988) for the description of this methodology.
} 
and to test whether $\operatorname{CSAR}_{\tau}$ differs from zero

$$
Z_{\tau}=\operatorname{CSAR}_{\tau} \sqrt{N}
$$

When corporate announcements increase the variance of returns, the above test tends to unfairly reject the null hypothesis (see Brown and Warner, 1985; Kalay and Lowenstein, 1985; Rosenstein and Wyatt, 1990). To check the sensitivity of our results with respect to event-induced variance changes, we also employ the event study method developed by Boehmer et al. (1991). Boehmer et al. suggest the following statistics to test whether $\mathrm{SAR}_{t}$ and $\mathrm{CSAR}_{\tau}$ are different from zero:

$$
\begin{aligned}
& T_{t}=\operatorname{SAR}_{t}\left(\frac{N-1}{\sum_{i=1}^{N}\left(\mathrm{SR}_{i t}-\mathrm{SAR}_{t}\right)^{2}}\right)^{1 / 2}, \\
& T_{\tau}=\operatorname{CSAR}_{\tau}\left(\frac{N-1}{\sum_{i=1}^{N}\left(\mathrm{CSR}_{i \tau}-\mathrm{CSAR}_{\tau}\right)^{2}}\right)^{1 / 2} .
\end{aligned}
$$

Here, $\mathrm{CSR}_{i \tau}$ is the cumulative standardized abnormal return for stock $i, T_{t}$ and $T_{\tau}$ are $t$-distributed random variables, and all other variables are the same as previously defined.

\subsection{Announcement day returns for high-and low-q companies}

A basic question this study seeks to answer is whether changes in capital expenditures have systematically different effects on the prices of high- and low- $q$ firms. Hence we calculate abnormal returns associated with announcements of capital expenditure decisions for the group of high- $q$ firms as well as for the group of low- $q$ firms. Table 3 reports both the average abnormal returns $\left(\mathrm{AAR}_{t}=\sum_{i} \mathrm{AR}_{i t} / N\right)$ and the average standardized abnormal returns $\left(\mathrm{SAR}_{t}=\sum_{i} \mathrm{SR}_{i t} / N\right)$ for days -5 through +5 . For days -30 through -6 and days 6 through 10, we report, for brevity, the cumulative average abnormal returns $\left(\mathrm{CAAR}_{\tau}\right)$ and the cumulative standardized abnormal returns $\left(\mathrm{CSAR}_{\tau}\right)$ during respective subperiods. ${ }^{7}$

The results show that the market on average reacts favorably to the announcements by high- $q$ firms of increases in capital expenditures. Both $Z$ and $T$ statistics indicate that excess returns on the announcement day are positive and significant. Moreover, the number of positive standardized abnormal returns (SR) is significantly greater than the number of negative SR on the an-

\footnotetext{
${ }^{7} \mathrm{CAAR}_{\tau}$ is measured by the intertemporal summation of the average abnormal returns over a given period, i.e., $\mathrm{CAAR}_{\tau}=\sum_{\tau} \mathrm{AAR}_{t}$, where $\sum_{\tau}$ denotes the summation over $t=v$ through $\tau, v$ and $\tau$ are, the beginning and ending day of each CAAR calculation, respectively.
} 


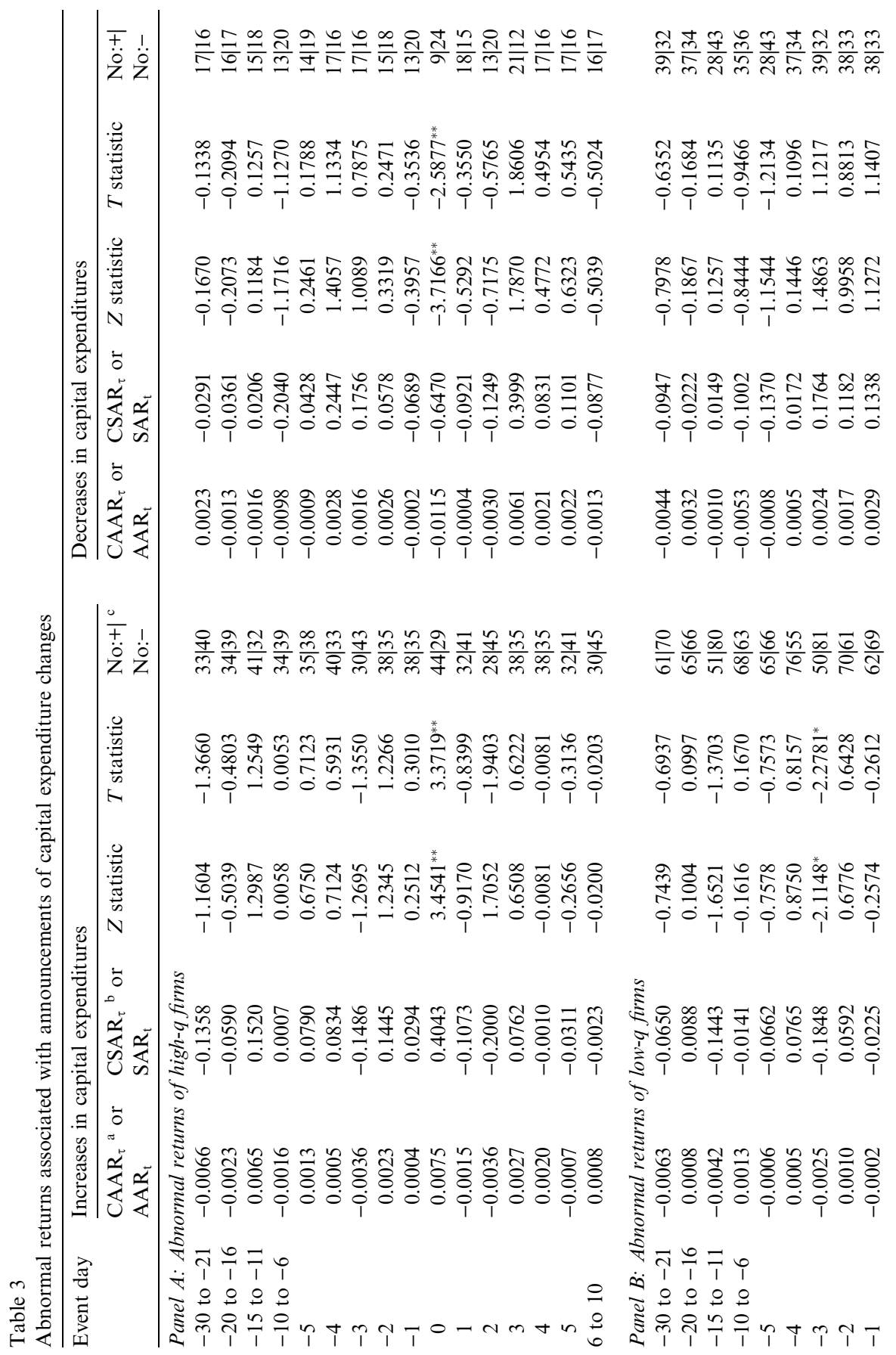




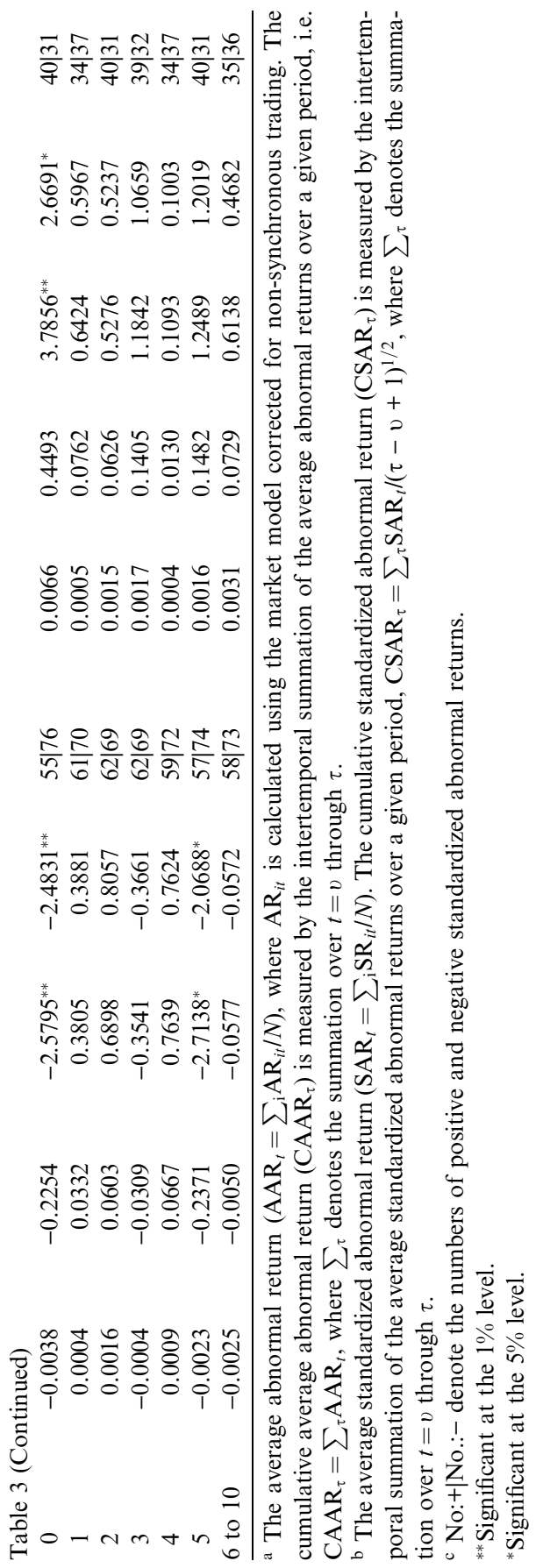


nouncement day, suggesting that the results are not due to a few large outliers. An inspection of the distribution of the announcement day abnormal returns, shown in Fig. 1, further confirms the above finding.

The results, however, show that the share price change associated with announcements by low- $q$ companies of increases in capital expenditures is quite different from the one associated with the same announcement by high- $q$ companies. Panel B of Table 3 shows that these companies experience significant share price decreases around such announcements. Both $T$ and $Z$ statistics indicate that abnormal returns on day $-3,0$, and 5 are significantly negative for these companies. These results are consistent with our conjecture that the market reaction to firms' capital spending decisions will be unfavorable when their investment opportunities are perceived to be non-lucrative.

The abnormal returns associated with corporate announcements of decreases in capital expenditures are also systematically different between high- and low- $q$ companies. Our results show that such announcements made by low- $q$ companies are received favorably by the market, while the same announcements are unfavorably received when made by companies with valuable investment opportunities.

Overall, these results support our conjecture that a critical variable influencing the market's reaction to a firm's capital spending decision is the market's perception of the quality of its investment opportunities. For firms with valuable investment opportunities, the market reacts favorably to increases in their capital budgets, but negatively to decreases in capital budgets. On the contrary, the market reacts negatively to increases in their capital budgets, but positively to decreases in capital budgets for firms with poor investment opportunities.

To examine the sensitivity of our results, abnormal share price changes are also measured using mean-adjusted returns (see Brown and Warner, 1980). In this case, excess returns are measured by subtracting the mean return during the estimation period from daily stock returns during the event period. The results are qualitatively identical to those presented here. ${ }^{8}$ Hence we conclude that our results are quite robust and not sensitive to how the abnormal returns are measured.

\subsection{Industry influence on announcement day returns}

The basic premise of our study is that it is not whether a firm belongs to a high-technology or low-technology industry but whether the firm has growth potential which determines the market's reaction to capital expenditure decisions. To examine this issue more directly, we run the following regression

\footnotetext{
${ }^{8}$ The results are available from the authors upon request.
} 

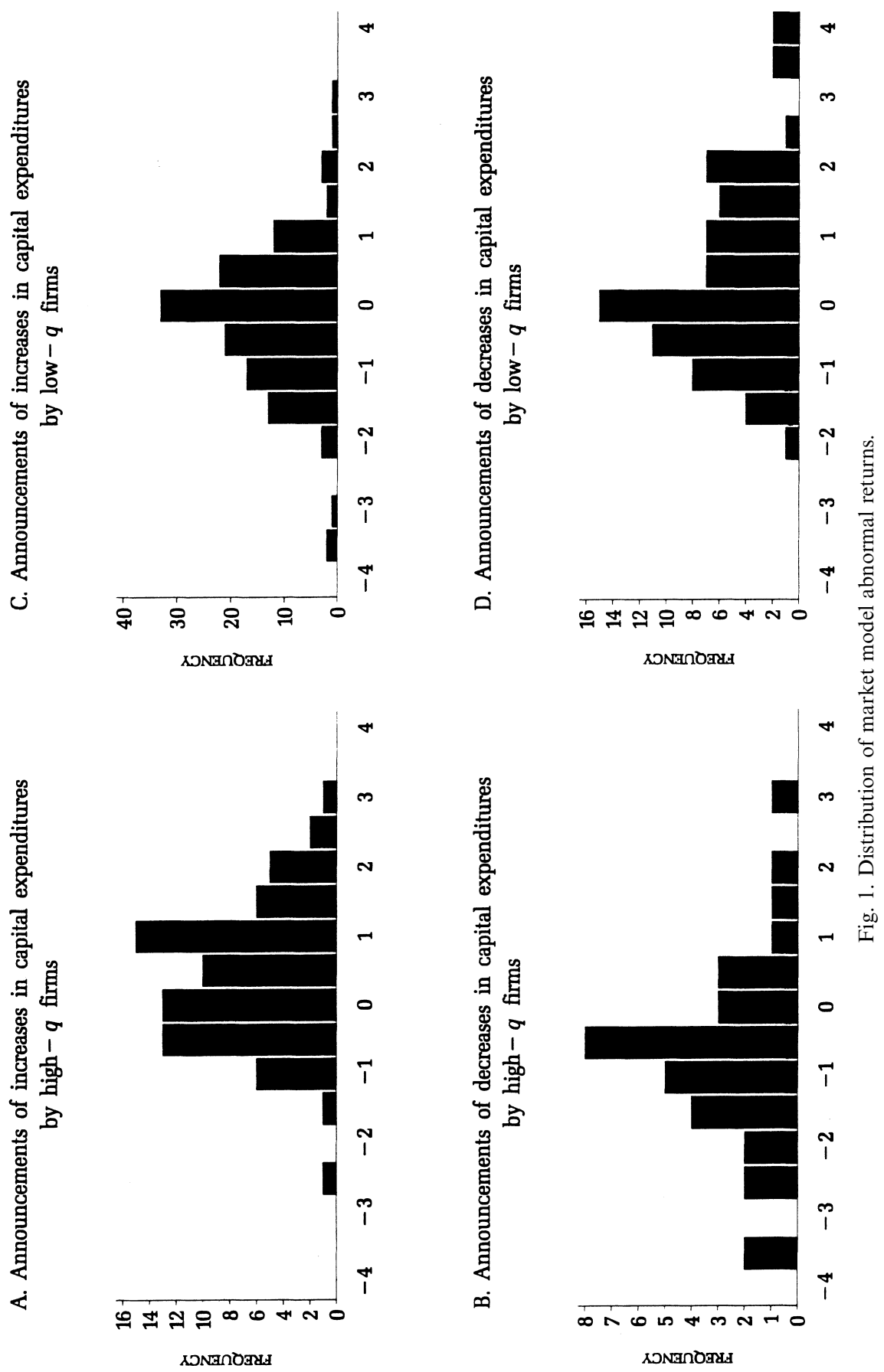
model for the group of firms in high-technology industries as well as for the group of firms in low-technology industries. ${ }^{9}$

$$
\mathrm{SR}_{i 0}=\beta_{0}+\beta_{1} D_{\mathrm{LD}}+\beta_{2} D_{\mathrm{HI}}+\beta_{3} D_{\mathrm{HD}}+\epsilon_{i}
$$

where $\mathrm{SR}_{i 0}$ is the standardized abnormal return of stock $i$ on the announcement date, $D_{\mathrm{LD}}$ a dummy variable representing the announcement by low- $q$ firms of decreases in capital expenditures, $D_{\mathrm{HI}}$ a dummy variable representing the announcement by high- $q$ firms of increases in capital expenditures, $D_{\mathrm{HD}}$ a dummy variable representing the announcement by high- $q$ firms of decreases in capital expenditures, and $\epsilon_{i}$ is an error term. Notice that the intercept term $\left(\beta_{0}\right)$ captures the market's reaction to the announcement by low- $q$ firms of increases in capital expenditures. The above regression equation is estimated using both the market model abnormal returns and mean-adjusted abnormal returns.

According to our hypotheses, we expect that $\beta_{0}<0, \beta_{1}>0, \beta_{2}>0$, and $\beta_{3}<0$ regardless of whether the above regression model is estimated using the sample of firms in high-technology industries or the sample of firms in low-technology industries. On the contrary, if a firm's industry affiliation (i.e. high- vs. low-technology industries or industrial vs. utility industries) has, as previous studies have implicated, important bearings on market reactions to capital expenditure decisions, we would expect otherwise. For example, if the announcements by high-technology firms of increases in capital expenditures are favorably received by the market, while the same announcements by low-technology firms are negatively received, one would expect the expected sign of $\beta_{2}$ to be positive for high-technology firms, but negative for low-technology firms.

Table 4 presents the regression results. Notice that the market reacts favorably to the announcements of increases in capital expenditures for the group of high- $q$ firms, regardless of their industry affiliations. Similarly, the market reacts favorably to the announcements of decreases in capital expenditures for the group of low- $q$ firms in both high- and low-technology industries. Moreover, we find that announcements by high-technology firms of increases in capital expenditures exert a negative impact on share prices when the market's perceived quality of those firms' investment opportunities is poor. Similarly, empirical evidence reveals that announcements of decreases in capital spending by low-technology firms exert a negative, not positive, impact on share prices when they have high $q$ ratios. ${ }^{10}$ On the whole, these results strongly support

\footnotetext{
${ }^{9}$ See Lang et al. (1989) for this methodology.

${ }^{10} \mathrm{We}$ also find that the announcements by high-technology firms of decreases in capital spending exert a negative impact on share price when they are high- $q$ firms. The estimated coefficients, however, are not statistically significant.
} 
Table 4

Cross-sectional regressions of standardized abnormal returns

\begin{tabular}{|c|c|c|c|c|}
\hline & \multicolumn{2}{|c|}{ Low-technology firms } & \multicolumn{2}{|c|}{ High-technology firms } \\
\hline & $\begin{array}{l}\text { Market model } \\
\text { abnormal return }\end{array}$ & $\begin{array}{l}\text { Mean-adjusted } \\
\text { abnormal return }\end{array}$ & $\begin{array}{l}\text { Market model } \\
\text { abnormal return }\end{array}$ & $\begin{array}{l}\text { Mean-adjusted } \\
\text { abnormal return }\end{array}$ \\
\hline Intercept ${ }^{a}$ & $\begin{array}{l}-0.1698 \\
(-1.32)\end{array}$ & $\begin{array}{l}-0.1326 \\
(-1.01)\end{array}$ & $\begin{array}{c}-0.3721 \\
\left(-2.15^{*}\right)\end{array}$ & $\begin{array}{l}-0.2119 \\
(-1.30)\end{array}$ \\
\hline $\begin{array}{l}\text { Low } q \text { / } \\
\text { decrease } \\
\text { capital } \\
\text { expenditure } \\
\text { dummy }{ }^{b}\end{array}$ & $\begin{array}{r}0.6300 \\
\left(2.88^{* *}\right)\end{array}$ & $\begin{array}{r}0.6299 \\
\left(2.81^{* *}\right)\end{array}$ & $\begin{array}{r}0.7953 \\
\left(2.79^{* *}\right)\end{array}$ & $\begin{array}{r}0.7507 \\
\left(2.80^{* *}\right)\end{array}$ \\
\hline $\begin{array}{l}\text { High } q \text { / } \\
\text { increase } \\
\text { capital } \\
\text { expenditure } \\
\text { dummy }^{c}\end{array}$ & $\begin{array}{r}0.6024 \\
\left(2.53^{* *}\right)\end{array}$ & $\begin{array}{c}0.4578 \\
\left(1.88^{*}\right)\end{array}$ & $\begin{array}{r}0.7438 \\
\left(2.99^{* *}\right)\end{array}$ & $\begin{array}{l}0.5130 \\
\left(2.20^{*}\right)\end{array}$ \\
\hline $\begin{array}{l}\text { High } q \text { / } \\
\text { decrease } \\
\text { capital } \\
\text { expenditure } \\
\text { dummy }{ }^{\mathrm{d}}\end{array}$ & $\begin{array}{l}-0.6650 \\
\left(-2.07^{*}\right)\end{array}$ & $\begin{array}{l}-0.8227 \\
\left(-2.49^{* *}\right)\end{array}$ & $\begin{array}{l}-0.0495 \\
(-0.16)\end{array}$ & $\begin{array}{l}-0.2132 \\
(-0.71)\end{array}$ \\
\hline$F$ statistic & $6.980^{* *}$ & $6.943^{* *}$ & $4.969^{* *}$ & $4.534^{* *}$ \\
\hline Adjusted $R^{2}$ & 0.0819 & 0.0815 & 0.1019 & 0.0917 \\
\hline
\end{tabular}

a The intercept term captures the abnormal return associated with announcements of increases in capital expenditures made by low- $q$ companies (i.e. firms with $q<1$ )

${ }^{\mathrm{b}}$ Dummy variables representing announcements of decreases in capital expenditures made by low$q$ companies (i.e. firms with $q<1$ ).

${ }^{c}$ Dummy variables representing announcements of increases in capital expenditures made by high$q$ companies (i.e. firms with $q>1$ ).

${ }^{d}$ Dummy variables representing announcements of decreases in capital expenditures made by high$q$ companies (i.e. firms with $q>1$ ).

${ }^{\text {e }}$ Figures in parentheses are $T$-statistics.

* Significant at the $5 \%$ level.

${ }^{* *}$ Significant at the $1 \%$ level.

our proposition that it is a firm's growth potential rather than its industry affiliation which will dictate the market's reaction to its investment decision.

Our results, however, show that the market reaction to announcements of increases in capital spending by low- $q$ firms in low-technology industries is not statistically significant. One possible interpretation of this result is that capital spending decisions of low- $q$ firms in low-technology industries may rarely have important strategic value. For these firms, there would be no compelling reason to keep capital spending plans private until the last minute. Therefore, the information may be shared with outsiders well before its official announcement. As a result, capital spending decisions by these firms may not come as a 
surprise when they are announced, and thus excess returns would not accrue in response to the announcements. ${ }^{11}$

Our empirical results also suggest that the market's response to corporate announcements is asymmetric between good and bad decisions. That is, the market tends to respond strongly to good decisions (e.g. increased capital spending by high- $q$ firms or decreased capital spending by low- $q$ firms), but the market's reaction tends to be less prominent for bad decisions (e.g. decreased capital spending by high- $q$ firms or increased capital spending by low- $q$ firms). In fact, Table 4 shows that the majority of coefficient estimates with negative expected sign are not statistically significant. This is a puzzling result because there is no reason to believe that the market's ability to recognize value-increasing decisions should differ from it's ability to recognize value-decreasing decisions.

\section{Conclusion}

In this study, we examine the impact of corporate capital expenditure decisions on share prices. Although previous studies suggest that the market tends to react more favorably to the capital spending decisions of high-technology firms, their categorization of firms lacks sound economic reasoning. We argue that share price reaction to a firm's capital expenditure announcements depends more on the market's assessment of the quality of its investment opportunities than its industry affiliation.

Empirical evidence is generally consistent with our conjectures. We find that: (1) announcements of increases (decreases) in capital spending result in positive share price changes among firms with $q$ ratios of greater (less) than unity, regardless of their industry affiliations, (2) announcements by high-technology firms of increases in capital expenditures result in negative share price changes when the market's perceived quality of their investment opportunities is poor, and (3) announcements by low-technology firms of decreases in capital spending exert a negative impact on share prices when they are high- $q$ firms. These results are supportive of our belief that it is a firm's growth prospects rather than its industry affiliation which determine the market's reaction to capital expenditure decisions.

\footnotetext{
${ }^{11}$ For high- $q$ firms, however, capital expenditure decisions may have significant strategic value. Hence, capital investment plans of these firms may not be shared with outsiders prior to the announcement (although there may be some involuntary leakage just prior to the announcement). This would give such firms lead time over rivals which may be predisposed to imitate their innovations. In such cases, because they are surprises, announcements of increases in capital expenditures may result in excess returns accruing to shareholders. Our empirical results are consistent with this view.
} 
The results of this study are significant because they offer evidence that the $q$ ratio indeed measures the marginal profitability of the firm's investment opportunities (or at least the market's perception of it). So far, macroeconomists and financial theorists have not uniformly agreed that $q$ is a reasonable measure of the firm's investment opportunity set. In our study, we take a robust measure of the firm's investment policy on the margin (i.e. the announced changes in capital expenditures) and we find that the market updates its expectations about the firm's future profitability. This updating is consistent with the view of $q$ as a measure of profitability of the firm's marginal investment opportunities.

\section{Acknowledgements}

The authors are grateful to two anonymous referees for their valuable comments. The authors thank Ashay Desai for research assistance. This work was supported in part by a grant from the Fogelman College Faculty Research Program. This support does not necessarily imply endorsement of research conclusions by the university or college.

\section{Appendix A. Calculation of Tobin's $q$}

Tobin's $q$ is defined as the ratio of the market value of assets to the replacement cost of assets. Below we present a detailed description of the computational procedures of these variables, which are largely based on Lindenberg and Ross (1981).

\section{A.1. Market value of assets}

The market value of a firm's assets is the summation of the market values of common stock, preferred stock, short-term liabilities, and long-term debt.

\section{A.1.1. Market value of common stock}

The market value of common stock is obtained by multiplying the fiscalyear-end closing price (Compustat Data \#24) by the number of common shares outstanding (\#25).

\section{A.1.2. Market value of preferred stock}

The market value of preferred stock is approximated by the capitalized value of preferred dividends (\#19), where the yield on medium-grade industrial bonds (from Moody's Industrial Manual) is used as the discount rate. 


\section{A.1.3. Market value of short-term liabilities and long-term debt}

We use the book value of current liabilities (\#5) as an estimate of their market value. The market value of long-term debt is calculated using the Lindenberg and Ross procedure.

The book value of long term debt (\#9) can be decomposed into two components: debt with known maturity and debt with unknown maturity. The known maturity portion consists of bonds maturing in year 2 through year 5 (\#91\#94) and bonds issued in the current year (which is assumed to mature in 20 years).

The unknown maturity portion of debt is equal to the difference between the total long term debt and the known maturity debt [i.e. $\# 9-(\# 91+\ldots+\# 94+\# 111)]$. We assume that the unknown maturity debt is distributed evenly over the years for which the maturity information is not available (i.e. year 6 to year 19 relative to the current year).

We assume that debt maturing in year $t$ has been issued in year $t-20$ with a coupon rate equal to the average yield for BAA bonds obtained from Moody's Investors Service.

Then we discount these payments with the bond yield from the current year to obtain the estimate of the market value of debt for that year.

\section{A.2. Replacement cost of assets}

Assets of a firm can be categorized into four groups: quick assets (i.e. current assets, excluding inventory), inventory, plant and equipment, and investments in unconsolidated subsidiaries, intangibles and other investments. The replacement costs of these assets are calculated using the following procedures.

\section{A.2.1. Quick assets}

The book value of quick assets (\#4-\#3) is used as the proxy for their replacement costs.

\section{A.2.2. Inventory}

If the firm uses the FIFO method of accounting, the replacement cost of inventory (RVINV) equals its book value (\#3). If the firm uses LIFO, the following adjustment is made. In the base year, $t, \mathrm{RVINV}_{t}$ is set equal to the book value (\#3). RVINV in the following year is calculated by adjusting for the inflation and the change in the inventory. For example, $\mathrm{RVINV}_{t+1}$ equals $\operatorname{RVINV}_{t} \times\left(1+I_{t+1}\right)+\left(\# 3_{t+1}-\# 3_{t}\right)$, where $I_{t+1}$ is the rate of inflation and \#3 is the book value of inventory in each year. If the firm uses more than one method of inventory valuation, the book values are combined with the adjusted values using weights derived from the ranking of methods reported in Compustat (\#59). The following weights are from McConnell and Servaes (1990). 


\begin{tabular}{lll}
\hline $\begin{array}{l}\text { Reported number of inventory } \\
\text { valuation method }\end{array}$ & Rank of LIFO & LIFO as weight \\
\hline 1 & 1 & 1 \\
2 & 1 & $2 / 3$ \\
2 & 2 & $1 / 3$ \\
3 & 1 & $1 / 2$ \\
3 & 2 & $1 / 3$ \\
3 & 3 & $1 / 6$ \\
\hline
\end{tabular}

\section{A.2.3. Plant and equipment}

The average age (AA) of plant and equipment is assumed to equal the ratio of accumulated depreciation to depreciation for the year (i.e. $\mathrm{AA}=(\# 7-\# 8)$ / $\# 14)$. Then the replacement cost (RVPE) is equal to the net value of plant and equipment multiplied by the current GNP deflator and divided by the GNP deflator AA years ago (i.e. $\mathrm{RVPE}=\# 8 \times\left(\mathrm{GNP}_{t} / \mathrm{GNP}_{t-\mathrm{AA}}\right)$, where $\mathrm{GNP}_{t}$ is the GNP deflator for fixed non-residential investment in the current year $t$ ).

\section{A.2.4. Investments in unconsolidated subsidiaries, intangibles and other invest- ments}

The same approach in A.2.2 for the LIFO inventory is used to estimate the replacement value of investments in unconsolidated subsidiaries, intangibles and other investments (\#31-\#33). Finally, the replacement cost of assets equals the sum of those values determined in Sections A.2.1-A.2.4.

\section{References}

Barclay, M.J., Litzenberger, R.H., 1988. Announcement effects of new equity issues and the use of intraday price data. Journal of Financial Economics 21, 71-99.

Boehmer, E., Musumeci, J., Poulsen, A., 1991. Event study methodology under conditions of event-induced variance. Journal of Financial Economics 30, 253-272.

Brown, S., Warner, J., 1980. Measuring security price performance. Journal of Financial Economics 8, 205-258.

Brown, S., Warner, J., 1985. Using daily stock returns: The case of event studies. Journal of Financial Economics 14, 3-31.

Chan, S.H., Gau, G.W., Wang, K., 1994. Stock market reaction to capital investment decisions: Evidence from business relocations. Journal of Financial and Quantitative Analysis 30, 81-100.

Chan, S.H., Martin, J.D., Kensinger, J.W., 1990. Corporate research and development expenditures and share value. Journal of Financial Economics 26, 255-276.

Denis, D., 1994. Investment opportunities and the market reaction to equity offerings. Journal of Financial and Quantitative Analysis 29, 159-177.

Eades, K., Hess, P., Kim, E.H., 1985. Market rationality and dividend announcements. Journal of Financial Economics 14, 581-604. 
Jung, K., Kim, Y., Stulz, R., 1996. Timing, investment opportunities, managerial discretion, and the security issue decision. Journal of Financial Economics 42, 159-185.

Kalay, A., Lowenstein, U., 1985. Predictable events and excess returns: The case of dividend announcement. Journal of Financial Economics 14, 423-449.

Lang, L.H.P., Litzenberger, R.H., 1989. Dividend announcements: Cash flow signalling vs. Free cash flow hypothesis? Journal of Financial Economics 24, 181-191.

Lang, L.H.P., Stulz, R.M., Walkling, R.A., 1989. Managerial performance, Tobin's $q$, and the gains from successful tender offers. Journal of Financial Economics 24, 137-154.

Lang, L.H.P., Stulz, R.M., Walkling, R.A., 1991. A test of the free cash flow hypothesis: The case of bidder returns. Journal of Financial Economics 29, 315-336.

Lindenberg, E.B., Ross, S.A., 1981. Tobin's q ratio and industrial organization. Journal of Business $54,1-32$.

Loderer, C.F., Mauer, D.C., 1992. Corporate dividends and seasoned equity issues: An empirical investigation. Journal of Finance 47, 201-225.

Masulis, R.W., 1980. The effects of capital structure change on security prices: A study of exchange offers. Journal of Financial Economics 8, 139-177.

Masulis, R.W., 1983. The impact of capital structure change on security prices: Some estimates. Journal of Finance 38, 107-126.

McConnell, J.J., Muscarella, C.J., 1985. Corporate capital expenditure decisions and the market value of the firm. Journal of Financial Economics 14, 399-422.

McConnell, J.J., Servaes, H., 1990. Additional evidence on equity ownership and corporate value. Journal of Financial Economics 27, 595-612.

Ofer, A.R., Siegel, D., 1987. Corporate financial policy, information, and market expectations: An empirical investigation of dividends. Journal of Finance 42, 889-911.

Pilotte, E., 1992. Growth opportunities and the stock price response to new financing. Journal of Business 65, 371-394.

Rosenstein, S., Wyatt, J., 1990. Outside directors, board independence, and shareholder wealth. Journal of Financial Economics 26, 175-192.

Scholes, M., Williams, J., 1977. Estimating betas from non-synchronous data. Journal of Financial Economics 5, 309-327.

Warner, J., Watts, R., Wruck, K., 1988. Stock prices and top management changes. Journal of Financial Economics 20, 461-492. 